\title{
KONSERVASI TERUMBU KARANG SEBAGAI UPAYA MENJAGA EKOSISTEM DI LAUT
}

\author{
Jason Wirawan ${ }^{1)}$, Rudy Surya ${ }^{2)}$ \\ 1)Program Studi S1 Arsitektur, Fakultas Teknik, Universitas Tarumanagara, jasonwirawan18@gmail.com \\ 2) Program Studi S1 Arsitektur, Fakultas Teknik, Universitas Tarumanagara, rudys@ft.untar.ac.id
}

\begin{abstract}
Abstrak
Pemanasan global menjadi masalah yang sudah lama terjadi, dan berdampak pada sangat banyak aspek kehidupan khususnya pada ekosistem-ekosistem yang ada di bumi. Salah satu dampak yang paling besar adalah terhadap ekosistem laut, yang kualitasnya terus semakin menurun dikarenakan pengasaman laut yang terjadi. Pengasaman laut mengakibatkan banyak terumbu karang rusak karena mengalami pemutihan, menjadikannya tidak dapat dihuni oleh biota-biota laut. Kerusakan terumbu karang ini juga mempengaruhi kesejahteraan sosial masyarakat dunia, khususnya Indonesia yang merupakan negara maritim. Ekologi sudah banyak rusak karena campur tangan manusia yang terus menerus, sehingga membutuhkan langkah penyelesaian yang melampaui ekologi, dengan cara-cara yang radikal. Salah satu solusi adalah melakukan konservasi terumbu karang di Kepulauan Seribu yang diketahui masih banyak memiliki terumbu karang. Perbaikan pada terumbu karang akan memperbanyak organisme-organisme yang secara tidak langsung memperbaiki dampak pengasaman laut yang terjadi. Upaya yang dilakukan dengan menggunakan metode perancangan biomorfik, yaitu menjadikan alam sebagai dasar pemikiran setiap proses desain. Aspek-aspek yang tercakup dalam dasar pemikiran tersebut adalah berupa bentuk karakteristik fisik, kebiasaan, dan juga respon suatu objek alam. Konservasi terumbu karang secara strategis dan berkelanjutan adalah dasar pemikiran yang digunakan disini, karena merupakan fokus yang diambil dari permasalahan yang ingin diselesaikan. Dari dasar pemikiran tersebut terdapat beberapa program yang diwujudkan dalam bentuk dan ruang, yaitu berupa fasilitas konservasi terumbu karang dan edukasi terumbu karang. Serta juga program lain seperti pasar hasil laut sebagai pendukung perekonomian masyarakat. Upaya penjagaan ekosistem laut dilakukan melalui konservasi terumbu karang di Pulau Pari, sebuah pulau yang memiliki potensi besar karena terumbu karang yang beragam, tetapi banyak rusak karena kurangnya tanggung jawab manusia. Proyek fasilitas konservasi terumbu karang ini bukan hanya secara aktif mengajak masyarakat melakukan konservasi dan riset mengenai terumbu karang, tetapi juga berupaya meningkatkan kesadaran masyarakat Indonesia mengenai terumbu karang, yang merupakan aset yang sangat penting bagi aspek pariwisata Indonesia.
\end{abstract}

Kata kunci: Ekologi: Ekosistem laut; Pengasaman laut; Konservasi; Terumbu karang.

\begin{abstract}
Global warming has been a problem for years, and its impacts are spread around every aspects of life especially to the ecosystems of earth. One of the biggest threat is affecting sea ecosystem, which quality is being gradually downgraded because of ocean accidification. The acidification cause coral reefs to die of coral whitening, making the marine biotas lose their habitat. The coral reef issue also affects social life of people around the world, especially Indonesia, a maritime country. There are already a lot of damaged ecologies because of human behaviours. That being said, a beyond ecology respond is an urgency, along with radical methods. One of the solutions is to conserve the coral reefs in Kepuluan Seribu which known is having a lot of coral reefs. Repairing the coral reefs will multiply the organisms which also indirectly repairing the impacts of sea accidification. The method used in the design process is biomorphic method, the nature is becoming the base guideline of every design aspects. The aspects included in the guideline are the physical
\end{abstract}


features, behaviours, and also responses of a nature object. Strategic and sustainable coral reef conservation are the baseline used here, for it is the main focus to be solved. From the theoritical baseline used, there are few programs being realized in shapes and forms, which are the coral reefs conservation and education facility. There is also other program such as the seafood market to support people's economy. The contribution to preserve the sea ecosystem will be done through coral reef conservation in Pari Island, which has a lot of potential because of the wide variety of coral reefs, but is having a problem because of human behaviours. This project of coral reefs conservation facility is not only actively conservate and doing research about coral reefs, but also trying to raise the Indonesians awareness about coral reef, which is a valuable asset to tourism aspect of Indonesia.

Keywords: Ecology; Coral reefs; Conservation; Sea ecosystem; Sea acidification

\section{PENDAHULUAN}

\section{Latar Belakang}

Pemanasan global adalah fenomena meningkatnya suhu rata-rata atmosfer, lautan, dan daratan bumi secara menyeluruh (Wikipedia, 2021). Fenomena ini terjadi karena beberapa sebab, dan salah satu yang paling utama adalah banyaknya kandungan karbon dioksida di udara. Pemanasan global terus menimbulkan berbagai permasalahan ekologi yang terus bertambah parah seiring waktu. Salah satunya adalah pengasaman laut (Reef, 2021).

Pengasaman laut memiliki dampak negatif yang semakin lama semakin besar bagi ekosistem laut. Dampak yang paling nyata, adalah kerusakan terumbu karang, yang merupakan salah satu habitat asli dari banyak biota laut. Kerusakan ini jika tidak ditindaklanjuti, akan berdampak pada keseimbangan ekosistem secara keseluruhan (Reef, 2021).

Indonesia sebagai salah satu negara yang berada di "Coral Triangle" di Asia Tenggara mempunyai terumbu karang yang jenis-jenis sangat unik, mewakili sebanyak $30 \%$ dari spesies terumbu karang di dunia. Terumbu karang tersebut adalah salah satu daya tarik yang sangat berharga bagi negara Indonesia, khususnya di bidang pariwisata. Selain itu, terumbu karang juga sangat penting bagi keberlangsungan dan keseimbangan biota-biota pada ekosistem laut, karena terumbu karang merupakan habitat natural dari banyak hewan laut. Namun, sampai saat ini belum ada tindakan nyata dari masyarakat Indonesia untuk benar-benar melakukan perlindungan terhadap terumbu karang. Belum adanya fasilitas konservasi terumbu karang yang memadai secara keruangan juga menjadi penghambat bagi perbaikan terumbu karang secara luas.

\section{Rumusan Permasalahan}

a. Bagaimana konservasi terumbu karang dapat memberi dampak positif terhadap keseimbangan ekosistem laut?

b. Bagaimana arsitektur dapat membawa perubahan perilaku dan meningkatkan kesadaran masyarakat terhadap nilai terumbu karang?

c. Apa program yang secara spesifik dapat diwujudkan secara ruang untuk mencapai dampak positif yang diinginkan terhadap terumbu karang?

\section{Tujuan}

Untuk menciptakan suatu karya arsitektural yang dapat menjadi wadah bagi konservasi terumbu karang dan juga meningkatkan kesadaran masyarakat akan nilai terumbu karang di Indonesia, yang akan secara tidak langsung memperbaiki ekosistem laut secara keseluruhan. Juga manfaat yang hendak dicapai oleh perancangan tersebut yaitu :

a. Meningkatkan kesejahteraan masyarakat lewat peningkatan kualitas ekosistem terumbu karang. 
b. Menjadi acuan bagi masyarakat luas tentang karya arsitektural yang berkaitan dengan konservasi terumbu karang.

c. Berkontribusi dalam memperbaiki ekosistem perairan di Indonesia, khususnya yang berkaitan dengan terumbu karang.

\section{KAJIAN LITERATUR}

\section{Ekologi}

Ekologi adalah ilmu yang mempelajari interaksi antara sebuah organisme hidup dengan organisme lain dan dengan lingkungan sekitarnya. Komponen yang terdapat dalam sebuah ekologi adalah berupa komponen biotik (makhluk hidup) dan juga komponen abiotik (tak hidup). Konsep-konsep ekologi adalah berupa lingkungan, ekosistem, interaksi antar organisme, dan juga suksesi. Lalu ruang lingkup ekologi adalah berupa hierarki, keanekaragaman hayati, dan juga habitat. Semua pengertian tersebut berkaitan erat dengan pengertian melampaui ekologi.

\section{Melampaui Ekologi}

Melampaui ekologi memiliki arti sebuah kondisi ekosistem yang kondisi formasi sosialnya mengalami percepatan (Agustinus Sutanto, 2021). Ekosistem yang ada di kompres dan mengalami pemadatan waktu sebagai konsekuensinya. Percepatan ini berkaitan erat dengan perilaku makhluk hidup dan lingkungan, khususnya manusia. Terdapat definisi kedua dari melampaui ekologi yaitu ekologi yang diterjemahkan dalam logika berpikir arsitektural, yang memiliki beberapa variabel yang perlu dipenuhi seperti interaksi, interelasi, interkonektivitas, perilaku, sistem, dan batasan yang jelas. Dari kedua definisi melampaui ekologi tersebut, penulis dapat menyimpulkan bahwa melampaui ekologi khususnya dalam arsitektur adalah upaya seorang arsitek dalam mengembangkan potensi ataupun menyelesaikan permasalahan ekologi yang sudah ada, dengan tujuan untuk meningkatkan nilai kehidupan yang lebih baik bagi partisipan suatu ekologi. Juga terdapat beberapa parameter yang mendefinisikan melampaui ekologi, parameter tersebut berupa:

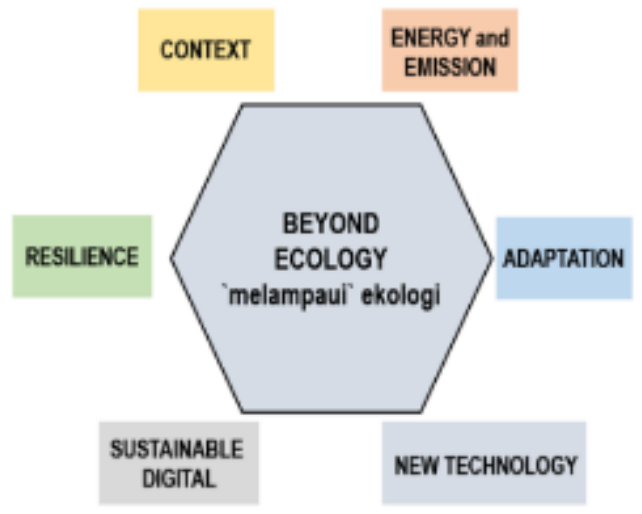

Gambar 1. Diagram Beyond Ecology

Sumber: Agustinus Sutanto, 2021

a. Context adalah kemampuan dalam melihat posisi tempat dalam hubungan dengan lingkungan (flora - fauna, biotic - abiotic) area sebuah konfigurasi keruangan akan ditempatkan.

b. Energy and Emission adalah kemampuan untuk menerapkan zero $\mathrm{CO} 2$ emission dalam proses pengoperasionalan bangunan dan meminimalisis efek karbon dalam material dan konstruksi.

c. Adaptation adalah kemampuan untuk melakukan riset dan desain yang berkaitan dengan berbagai dampak, seperti naiknya suhu bumi, naiknya permukaan laut, kekeringan, banjir, kelangkaan pangan, perubahan populasi. 
d. New Technology adalah kemampuan memanfaatkan teknologi terbaru untuk meningkatkan kualitas dan terapan-terapan ruang konstruksi dan program bangunan.

e. Sustainable Digital adalah kemampuan untuk melihat data-data lingkungan sebagai big data dalam menentukan taktik dan strategi dalam membangun kualitas spasial.

f. Resilience adalah kemampuan untuk membangun kelanjutan hunian dan pemulihan cepat setelah kejadian guncangan, bencana alam, gangguan listrik atau iklim.

\section{Pengasaman Laut}

Ocean Accidification atau pengasaman laut adalah suatu fenomena tingkat keasaman dan ion karbonat air laut berubah menjadi di bawah normal. Ion karbonat sangat penting untuk kalsifikasi, proses yang diperlukan untuk semua hewan laut yang membuat kerangka kalsium karbonat, seperti karang. Terdapat dua jenis dampak pengasaman laut, yaitu dampak sosial dan dampak biologis. Dampak sosial adalah berupa menurunnya jumlah perikanan komersil dan juga rekreasi terutama pada komunitas pesisir, juga peningkatan dampak perubahan iklim. Sedangkan dampak biologisnya adalah pengurangan tingkat pertumbuhan kerangka pada terumbu karang, dan juga kalsifikasi pada karang. Kalsifikasi menyebabkan peningkatan kerentanan karang terhadap penyakit, mengurangi kapasitas toleransi terhadap radiasi ultraviolet.

\section{Terumbu Karang}

Terumbu karang adalah sekumpulan hewan karang yang bersimbiosis dengan jenis tumbuhan alga yang disebut zooxanthellae (Castro $\mathrm{P}$, 2005). Terumbu karang merupakan habitat bagi berbagai spesies tumbuhan laut, hewan laut, dan mikroorganisme laut lainnya yang belum diketahui. Terumbu karang pada umumnya hidup di pinggir pantai atau daerah yang masih terkena cahaya matahari kurang lebih $50 \mathrm{~m}$ di bawah permukaan laut. Ekosistem terumbu karang sebagian besar terdapat di perairan tropis, sangat sensitif terhadap perubahan lingkungan hidupnya terutama suhu, salinitas, sedimentasi, dan eutrofikasi.

Untuk dapat bertumbuh dan berkembang biak secara baik, terumbu karang membutuhkan kondisi lingkungan hidup yang optimal, yaitu pada suhu hangat sekitar di atas $20^{\circ} \mathrm{C}$. Terumbu karang juga memilih hidup pada lingkungan perairan yang jernih dan tidak berpolusi. Hal ini dapat berpengaruh pada penetrasi cahaya oleh terumbu karang.

\section{Terumbu Karang di Indonesia}

Indonesia adalah negara kepulauan terbesar di dunia, terdiri dari lebih 17.000 buah pulau besar dan kecil, dengan panjang garis pantai mencapai hampir $81.000 \mathrm{~km}$ yang dilindungi oleh ekosistem terumbu karang, ekosistem padang lamun dan ekosistem mangrove. Indonesia merupakan salah satu negara terpenting di dunia sebagai penyimpan keanekaragaman hayati laut tertinggi. Di Indonesia terdapat 2,500 spesies molluska, 2,000 spesies krustasea, 6 spesies penyu laut, 30 mamalia laut, dan lebih dari 2,500 spesies ikan laut. Luas ekosistem terumbu karang Indonesia diperkirakan mencapai 2,5 juta ha). Dengan ditemukannya 362 spesies scleractinia (karang batu) yang termasuk dalam 76 genera, Indonesia merupakan pusat dari sebaran karang batu dunia. Ekosistem pesisir (padang lamun, mangrove dan terumbu karang) memainkan peranan penting dalam industri wisata bahari, selain memberikan pelindungan pada kawasan pesisir dari hempasan ombak dan gerusan arus. Selain itu ekosistem pesisir ini merupakan tempat bertelur, membesar dan mencari makan dari beaneka ragam biota laut yang kesemuanya merupakan sumber produksi penting bagi masyarakat pesisir.

Di samping peranannya yang penting, ekosistem terumbu karang Indonesia dipercaya sedang mengalami tekanan berat dari kegiatan penangkapan ikan dengan mempergunakan racun dan bahan peledak. Selain itu penangkapan berlebihan sedimentasi dan pencemaran juga merupakan ancaman yang tak kalah beratnya. Belakangan ini diperkirakan hamper 25 persen dari kehidupan di ekosistem terumbu karang telah mati, antara lain akibat dari peningkatan suhu 
mencapai sebesar $4^{\circ} \mathrm{C}$. Pada tahun 1994 LIPI mengadakan survei pada 371 buah station transek nasional dengan menggunakan prosedur standar pemantauan internasional. Hasilnya menunjukkan bahwa kondisi ekosistem terumbu karang Indonesia telah mengalami kerusakan yang sangat serius. Kerusakan tersebut semakin parah dan diperkirakan tahun 2050 terumbu karang di Indonesia sebagian besar sudah rusak (Reef Resilience Network, 2011).

\section{Teori Arsitektur Biomorfik}

Menurut Faisal (2020) Arsitektur Biomorfik adalah bagian dari desain arsitektur yang mengambil ide-ide dari kehidupan organik lewat bentuk fisik, sistem, ataupun pergerakan dari kehidupan tersebut. Sebagai sebuah contoh, jika mengambil kehidupan laut sebagai inti dari gagasan, karakteristik dari bangunan yang terbentuk akan mempunyai relasi dengan kehidupan laut tersebut. Karakteristik ini termasuk dalam program-program yang digunakan: konservasi dan edukasi kehidupan laut.

\section{METODE}

\section{Penentuan Program}

Metode yang digunakan untuk penentuan program adalah metode kualitatif, yaitu dimulai dari dasar-dasar teori yang berkaitan dengan isu yang diangkat, diproses hingga mencapai suatu hasil program.
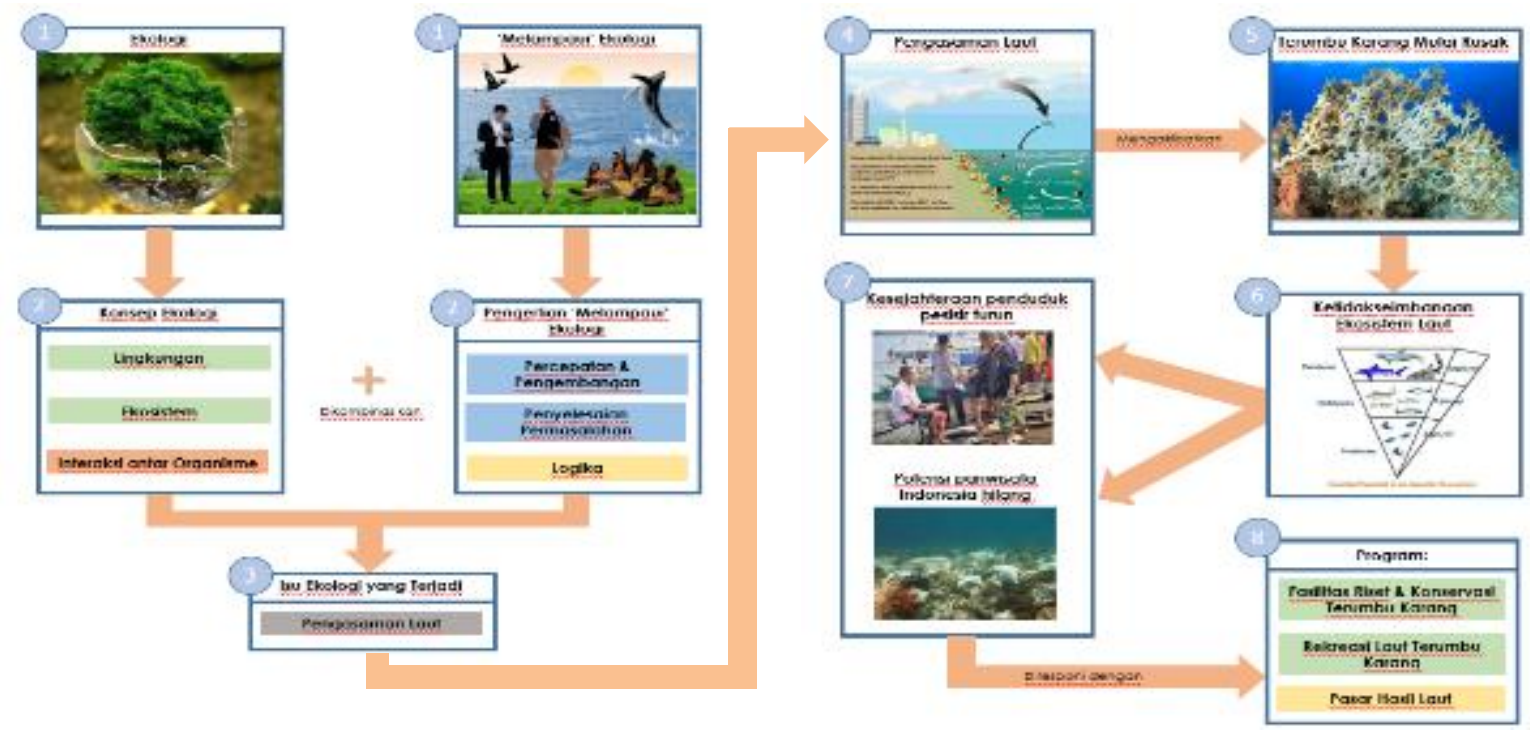

Gambar 2. Theoritical Framework Diagram Sumber: Ruslie, 2021

Pengasaman laut yang merupakan hasil dari pendefinisian antara ekologi dan melampaui ekologi diuraikan kembali menjadi dampak yang lebih spesifik yaitu terhadap terumbu karang. Dari karakteristik dan kebutuhan terumbu karang menghasilkan respon berupa rencana program yaitu fasilitas konservasi dan edukasi terumbu karang. Dari dampak yang dihasilkan oleh rusaknya terumbu karang yaitu menurunkan pendapatan masyarakat sekitar, dimasukkan program tambahan berupa pasar hasil laut sebagai upaya meresponi dampak tersebut.

\section{Penentuan Tapak}

Berdasarkan Reef Resillience Network, karakteristik habitat yang cocok untuk melakukan konservasi adalah berupa daerah yang kaya akan karbonat, kompleks terumbu karang dengan keanekaragaman tinggi yang diguyur baik oleh air laut, dan juga rumput lamun di sekitar karang. Terdapat juga aspek lain secara arsitektural yang perlu dipenuhi yaitu berupa prasarana 
kendaraan antara pulau yang sudah mendukung, antisipasi terhadap kondisi ekstrim di masa lalu, dan juga masih dalam batasan-batasan wilayah maritim Indonesia yang dapat dibangun, tidak memotong jalur laut internasional. Selanjutnya, dari kriteria tersebut dicari data yang berkaitan dengan terumbu karang di Indonesia dan juga mempertimbangkan permasalahan yang ada, yang pada akhirnya Pulau Pari di Kepulauan Seribu disimpulkan sebagai tapak terpilih.

\section{Proses Desain Gubahan}

Proses dilakukan dengan analisa secara makro, messo dan juga mikro mengenai tapak yang terpilih lalu menyimpulkan zoning dari setiap program yang sebelumnya sudah ditetapkan. Zoning tersebut lalu digabungkan dengan teori Arsitektur Biomorfik, yaitu teori yang menggunakan alam sebagai dasar desain. Pada proyek ini, secara spesifik menggunakan terumbu karang sebagai inspirasi desain. Karakteristik fisik dari terumbu karang yang digunakan adalah bentuk fisik dari karang Cyphastrea yang juga berada di sekitar Pulau Pari.

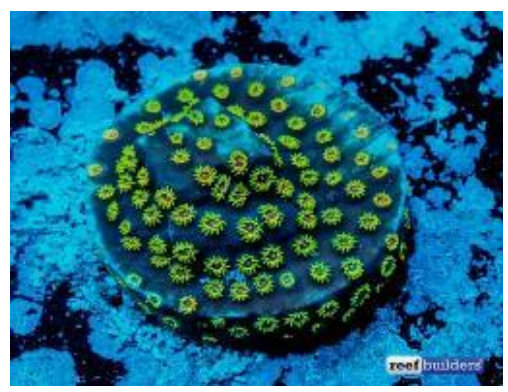

Gambar 3. Karang Cyphastrea

Sumber: https://reefbuilders.com/2015/10/26/cyphastrea-aquarium-coral/

Karakteristik lain dari terumbu karang yang digunakan sebagai metode pembentukan gubahan adalah kebiasaan terumbu karang untuk dapat berfotosintesis dengan sendirinya jika mendapat nutrisi dan juga sinar matahari yang cukup. Dari sini penulis menerapkannya dengan menggunakan sistem yang membuat bangunan dapat melakukan konservasi dengan sumber daya mandiri.

\section{DISKUSI DAN HASIL}

\section{Strategi Desain}

Konservasi adaptif berkelanjutan menjadi strategi atau konsep utama dari keseluruhan desain yang ingin dibentuk. Dalam program utama yaitu konservasi terumbu karang, penggunaan pencahayaan alami di keseluruhan bangunan dan juga pengolahan sumber daya konservasi berupa air menjadi bagian penting dari konsep ini. Maka dari itu dibutuhkan material dan juga fasad yang cukup terbuka pada bangunan.

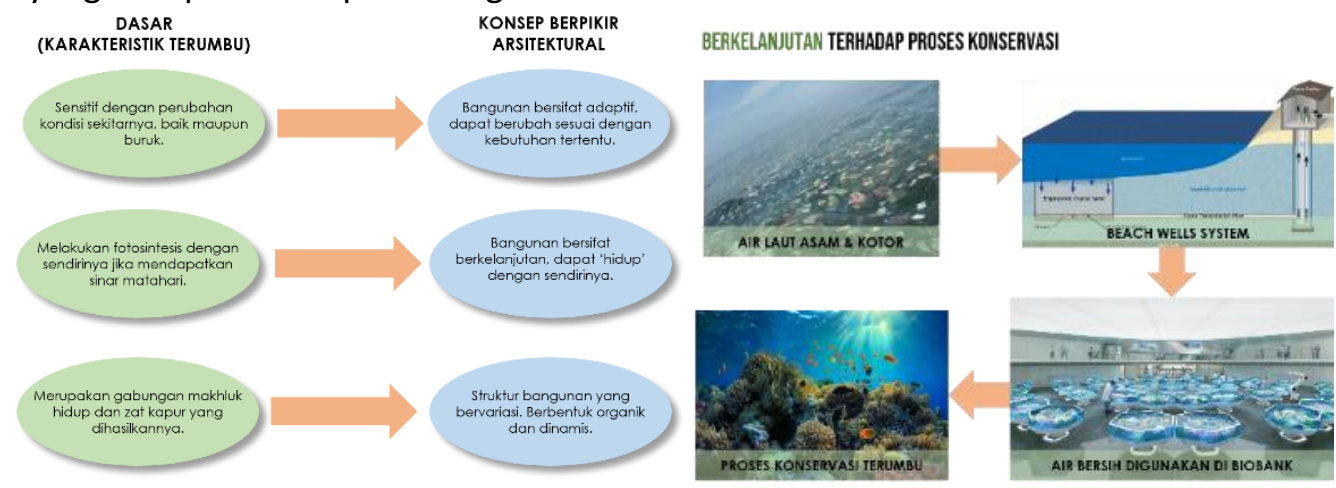

Gambar 4. Konsep Berpikir Arsitektural \& Konsep Berkelanjutan Sumber: Ruslie, 2021 


\section{Konsep Gubahan Massa}

Berdasarkan metode perancangan yang digunakan yaitu arsitektur biomorfik, karakter fisik terumbu karang menjadi dasar dari pembentukan massa. Salah satu terumbu karang yang berada di area Pulau Pari adalah jenis Cyphastrea yang akan menjadi konsep awal pembentukan gubahan.
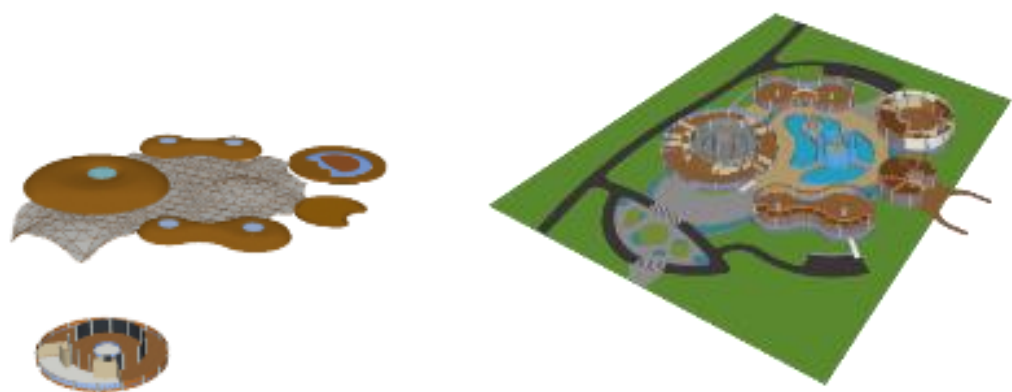

Gambar 5. Gubahan Massa Exploded

Sumber: Ruslie, 2021

Cyphastrea lalu diadaptasikan ke dalam beberapa massa bangunan sesuai dengan kebutuhan setiap program, dengan kolam dan aquarium konservasi di tengah sebagai vocal point bagi setiap massa yang ada. Peletakkan setiap massa program didasarkan oleh zoning akhir yang telah dibuat.

\section{Konsep Landsekap}

Landsekap yang terdapat secara eksisting pada tapak yang digunakan adalah berupa rumput dan juga pepohonan. Tanah yang berada di area tapak yang digunakan adalah jenis tanah podsol, yang memang cocok untuk rerumputan dan pepohonan. Mengenai peletakan vegetasi, pendekatan beyond ecology membuat perancangan harus memperhatikan kondisi lingkungan sekitar, sehingga vegetasi yang berada di dalam tapak secara eksisting tidak diubah sama sekali. Peletakan massa bangunan yang mengikuti kondisi landsekap yang ada sebelumnya.

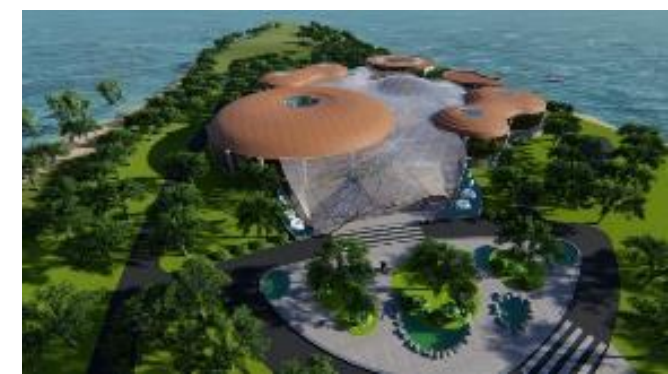

Gambar 6. Birdview Tapak \& Massa Keseluruhan Sumber: Ruslie, 2021

Di bagian depan tapak dibuat entrance garden sebagai penyambut pedestrian dikarenakan sebagian besar pengunjung merupakan pejalan kaki. Landsekap juga diberikan elemen air sesuai dengan program utama yang berhubungan juga dengan elemen air. Jalan yang melewati tapak merupakan jalan buatan dikarenakan bagian belakang tapak adalah lahan kosong yang berpotensi untuk digunakan di masa depan, sehingga perlu diberikan respon secara aksesibilitas yaitu membuat jalan yang memungkinkan pengunjung untuk mengaksesnya.

\section{Program}

Sesuai dengan isu yang dibahas dan juga analisis yang telah dilakukan, penulis dapat menyimpulkan pembagian program sebagai berikut: 


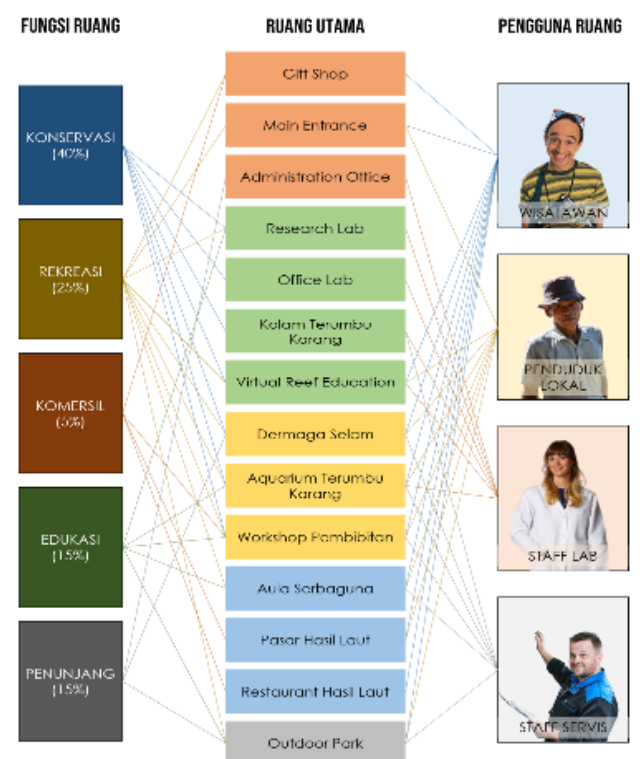

Gambar 7. Pembagian Program

Sumber: Ruslie, 2021

Program dibagi menjadi 5 bagian, yaitu konservasi sebesar 40\% sebagai program utama berupa kolam konservasi, laboratorium riset, dan aquarium terumbu karang. Lalu bagian rekreasi sebesar $25 \%$ untuk menarik pengunjung. Bagian edukasi sebesar $15 \%$ yang tergabung dengan bagian rekreasi berupa virtual reef education, workshop konservasi, dan perpustakaan kelautan. Bagian komersil sebesar $5 \%$ sebagai tambahan fasilitas untuk mendongkrak perekonomian masyarakat sekitar berupa pasar hasil laut. Dan terakhir bagian penunjang berupa outdoor park dan juga utilitas-utilitas lain.

\section{Zoning Program}

Dari program yang sudah dihasilkan dan digabungkan dengan analisis tapak yang dilakukan, menghasilkan zoning program pada tapak.

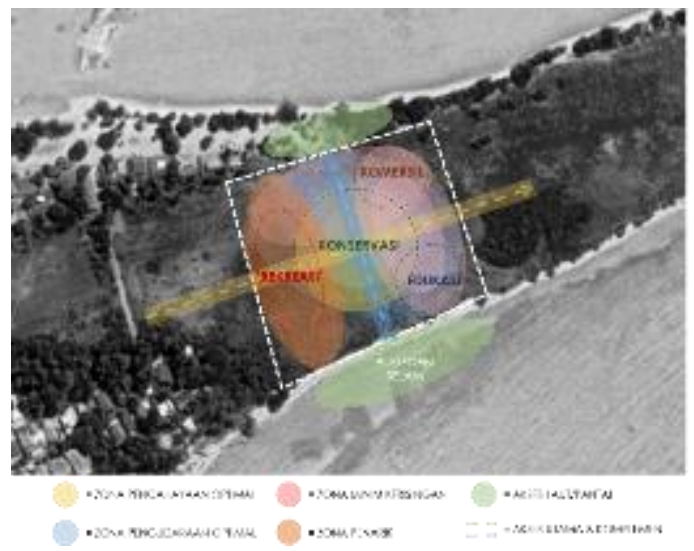

Gambar 8. Zoning Program

Sumber: Ruslie, 2021

Bagian konservasi diletakkan di bagian tengah tapak dikarenakan objek konservasi yaitu terumbu karang membutuhkan perlindungan dari pengudaraan dan kebisingan dari aktivitas kendaraan di sekitarnya. Bagian rekreasi diletakkan di bagian depan tapak untuk menarik pengunjung secara visual dan juga menerima pengunjung yang datang. Bagian komersil, edukasi, dan juga dermaga diletakkan di bagian belakang dan juga bersebelah dengan laut agar pengunjung dapat belajar secara aktual, juga ruang-ruangnya tidak terlalu terpengaruh oleh pengudaraan dan juga aktivitas manusia. 


\section{Desain Bangunan}
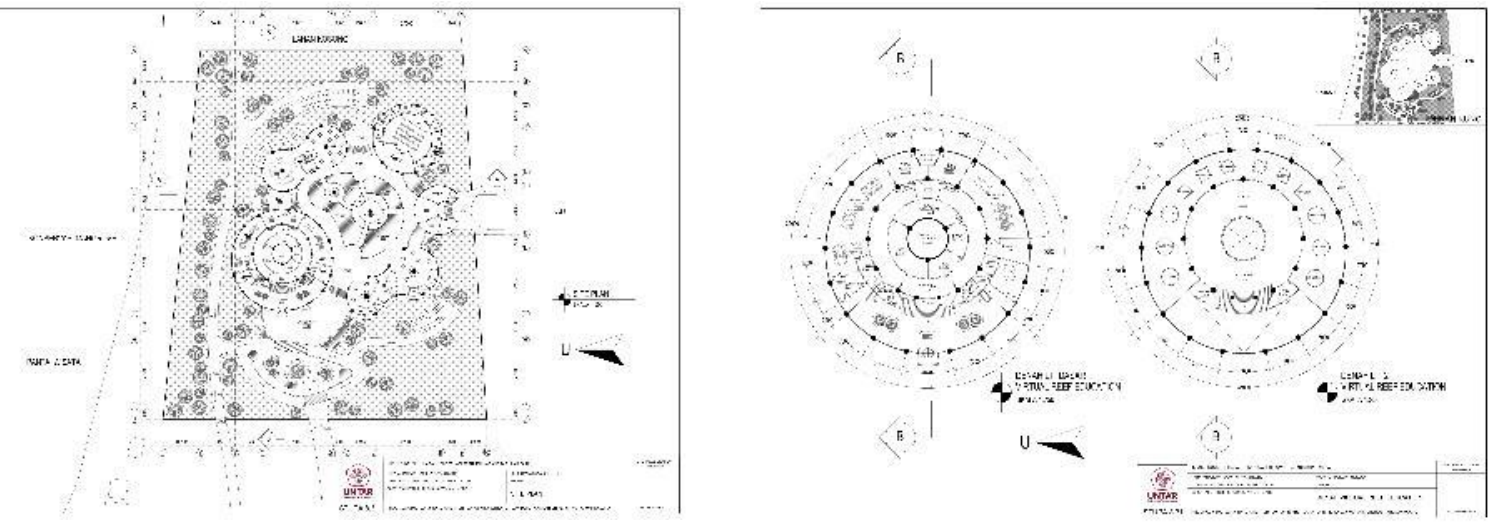

Gambar 9. Site Plan dan Denah Massa Utama

Sumber: Ruslie, 2021

Bangunan terbagi menjadi 5 bagian, yang disatukan oleh sirkulasi berserta kolam konservasi di tengah setiap massa. Layout per bangunan dibentuk dari gubahan massa yang disesuaikan dengan luasan program dan juga zoning per massa. Area sirkulasi juga memperhatikan pembagian antara sirkulasi pengujung dan juga pengelola pada setiap massa.

Dari desain yang terbentuk, lalu ditambahkan ornamen dan juga kusen-kusen dengan material alami sebagai fasad. Berikut merupakan tampak bangunan dari berbagai sisi:
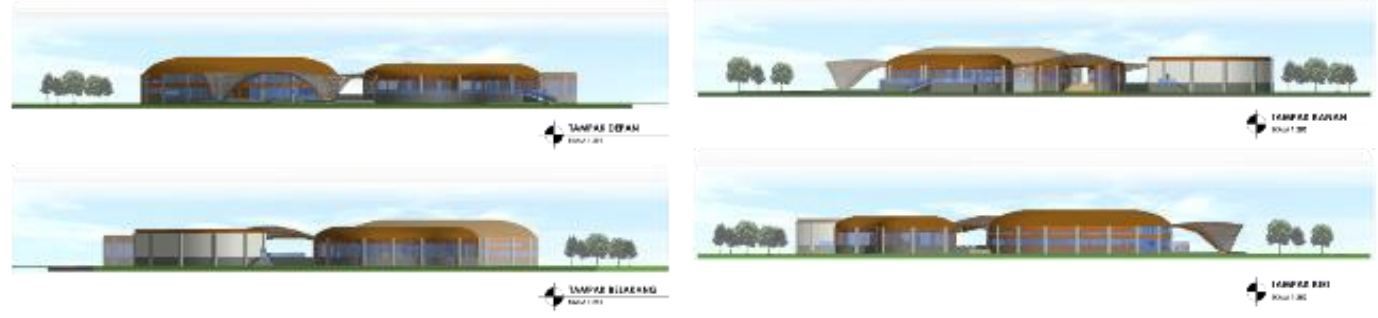

Gambar 10. Tampak Keseluruhan Massa

Sumber: Ruslie, 2021

\section{Perencanaan Utilitas}

Dari berbagai analisa dan metode yang dilakukan, penulis menyimpulkan sebuah konsep berupa Konservasi Adaptif Berkelanjutan yaitu bangunan menggunakan sistem yang akan mengurangi penggunaan sumber daya berlebihan dalam proses konservasi yang dilakukan. Secara spesifik, sistem yang digunakan adalah Beach Wells System.

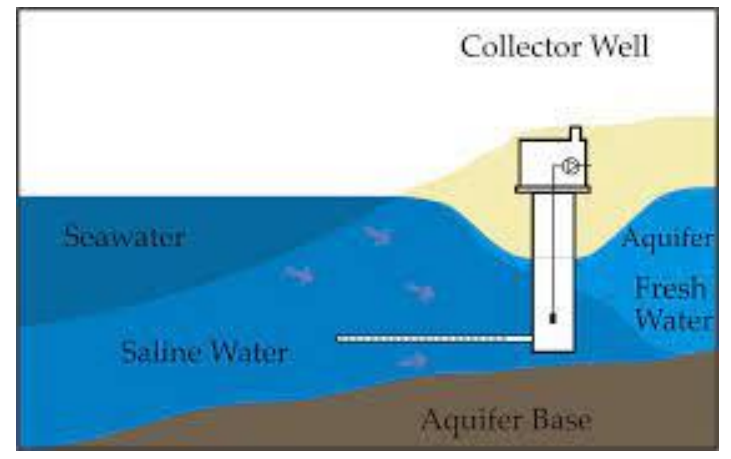

Gambar 11. Beach Wells System

Sumber: http://arwadex.net/sitecontent/uploads/editor/Arwadex2019/Presentations/4\%20-\%20S4-Thomas.pdf 
Sistem ini menyedot air laut dan mengolahnya sehingga air tersebut layak digunakan. Air yang sudah diolah ditampung di tangki penyimpanan lalu langsung didistribusikan ke dalam kolam konservasi dan kebutuhan program-program lain.

\section{KESIMPULAN DAN SARAN}

\section{Kesimpulan}

Tujuan akhir proyek ini adalah untuk melakukan konservasi secara nyata dan juga meningkatkan pengetahuan kesadaran masyarakat terhadap terumbu karang di Indonesia. Terumbu karang sebagai habitat bagi banyak biota laut, menjadi aspek penting bagi kualitas ekosistem laut. Melalui setiap program yang dibuat, dan juga dari setiap aspek yang di desain secara langsung berpengaruh terhadap kualitas hidup biota laut dan juga peningkatan perekonomian masyarakat sekitar yang terdampak dari permasalahan yang terjadi. Serta secara tidak langsung juga akan berkontribusi pada penyelesaian permasalahan pengasaman laut yang terjadi secara global.

\section{Saran}

Kualitas spasial dan juga kenyamanan manusia di dalam bangunan yang di desain merupakan aspek penting yang perlu diperhatikan lebih lanjut dalam proses yang dilakukan. Di satu sisi, perubahan lingkungan secara global maupun lokal yang banyak terjadi juga dapat menjadi acuan adaptasi proyek di masa depan.

\section{REFERENS}

Coremap.

$$
\text { (2016). Tentang Terumbu }
$$

Karang.

Retrieved

from

http://coremap.oseanografi.lipi.go.id/berita/520

Harrouk, C. (2020). archdaily.com. Retrieved from https://www.archdaily.com/950322/australia-is-building-the-worlds-first-coralconservation-facility?ad_source=search\&ad_medium=search_result_all

Hartmann, H. (2011, Juni). archdaily.com. Retrieved from https://www.archdaily.com/143563/cram-foundation-for-the-rehabilitation-andconservation-of-marine-animals-hidalgo-hartmann

Habibah, R. (2020). Perancangan Pusat Konservasi Terumbu Karang di Pantai Utara Lamongan Dengan Pendekatan Arsitektur Organik. Retrieved from http://etheses.uinmalang.ac.id/19396/1/15660008.pdf

Jormakka, K. (2007). Basic Design Methods. Boston: Birkhäuser Architecture.

Sutanto, A. (2020). Peta Metode Desain. Jakarta: Universitas Tarumanagara.

The Nature Conservancy. (2021). Ocean Acidification. Retrieved from https://reefresilience.org/stressors/ocean-acidification/

Winata, S. (2021, Januari). Eco-Logic. (S. Suwardana Winata, Performer) Online Class

about Ecologic.

Wikipedia. (2021). Coral Triangle. Retrieved from https://en.wikipedia.org/wiki/Coral_Triangle Wikipedia. (2021). Ekologi. Retrieved from https://id.wikipedia.org/wiki/Ekologi

Wikipedia. (2021). Pulau Pari, Kepulauan Seribu Selatan, Kepulauan Seribu. Retrieved from https://id.wikipedia.org/wiki/Pulau_Pari,_Kepulauan_Seribu_Selatan,_Kepulauan_Seribu

Wikipedia. (2021). Terumbu Karang. Retrieved from https://id.wikipedia.org/wiki/Terumbu_karang

Yonas et al. (2018). Pemetaan Sebaran Terumbu Karang Menggunakan Citra Satelit Spot-6 di Perairan Pulau Pari Kepulauan Seribu Jakarta. Retrieved from https://ejournal3.undip.ac.id/index.php/maquares/article/view/22552/20669 